\title{
Peningkatan Keterampilan Penggunaan Aplikasi Myob Accounting Bagi Siswa SMK Yabri Simpang Tiga Kota Pekanbaru Provinsi Riau
}

\author{
INDARTI \\ Universitas Lancang Kuning \\ Jln. Yos Sudarso KM 08 Rumbai Telp. (0761) 52581 \\ E-mail : indarti.ng1911@gmail.com
}

\begin{abstract}
Activities devotion was conducted in the vicinity of the school vocational (SMK) yabri the city of pekanbaru.The participants consists of the students of vocational high school (SMK) yabri still have not understand how to use accountancy softwares to do bookkeeping or financial reporting. Myob accounting as one of the to ease presentation of financial report. Devotion is expected to improve the presentation of a financial statement that faster, proper and accurate, and to make it easier for in understanding the presentation of in financial reporting in accordance with which time and provisions which was introduced by a high school vocational yabri pekanbaru .Through the increase in the use of software skill myob accounting in enhance the capacity of the presentation of financial reports, it is hoped the students motivated to study and understand the use of software myob accounting in order to support the performance of students on while working later on, not subsequently find it difficult if $\mathrm{i}$ can make accountancy softwares in its business. A method of execution for activities devotion this is through socialization how provide an annual report in accordance with the application of accounting according to the standard of the generally accepted by using softwae myob accounting to high school students vocational yabri pekanbaru the subdistrict simpang three pekanbaru to be taken as many as for approximately 30 students. The result of devotion this is the increasing the knowledge and the understanding of participants to software myob accounting an evaluation through answer post test that rises significant where $90 \%$ already knows myob accounting and he knows benefits, previously only $30 \%$ knew myob accounting and $40 \%$ know of the benefits of myob accounting.Even with the socialization by means of simulation one case company optimism participants we come to the ability to use application software myob accounting where $90 \%$ said could use application software myob accounting.
\end{abstract}

Keywords: $M Y O B$ Accounting, Skill

MYOB adalah singkatan dari Mind Your Own Business, adalah paket aplikasi software akuntansi yang dikembangkan pertama kali oleh $M Y O B$ Pte. Ltd. yang berdomisili di Australia.Penggunaan dan akses data yang cepat dari sebuah laporan keuangan hingga ke sumber transaksi dan terhubung dengan aplikasi Microsoft Office (excel, word, dan outlock) serta aplikasi lainnya merupakan alasan mengapa $M Y O B$ banyak memperoleh penghargaan pada tingkatan dunia dan sangat terkenal di seluruh dunai. $M Y O B$ sangat dekat dengan dunia bisnis, sehingga $M Y O B$ merupakan program yang digunakan untuk pencatatan akuntansi suatu usaha, bisnis atau kegiatan usaha lainnya dengan mudah, cepat, akurat dan efisien. $M Y O B$ merupakan program akuntansi yang paling populer dan cocok digunakan untuk perusahaan berskala kecil dan menengah (Sohidin, 2011: 1).

SMK Yabri Simpang Tiga yang berlokasi di Jalan Kaharuddin Nasution Kota Pekanbaru merupakan salah satu SMK yang ada di kota Pekanbaru. Dalam mempelajari akuntansi, selain siswa menguasai pengelolaan data akuntansi secara manual juga harus mengetahui sistem akuntansi dengan komputer. Sesuai dengan perkembangan teknologi, penggunaan komputer sudah merupakan hal umum dalam pengolahan data akuntansi agar lebih cepat, tepat dan akurat. Penggunaan komputer untuk mendukung dalam bidang akuntansi merupakan kebutuhan yang harus 
dipenuhi untuk bekal bagi siswa lulusan program Akuntansi. Hal ini penting untuk menciptakan tenaga profesional dalam bidang akuntansi sesuai dengan kebutuhan dunia kerja sehingga mampu meminimalisir angka pengangguran intelektual di Indonesia.

Salah satu upaya untuk meningkatkan akuntabilitas, pengendalian internal dan keamanan organisasi adalah dengan mengurangi adanya ketidak pahaman yang melaksanakan pencatatan dan membatasi kesalahan pencatatan menggunakan sistem pencatatan yang terkomputerisasi. Untuk itu kegiatan ini bertujuan untuk memberikan pemahaman bagi siswa agar dapat mengimplementasikan sistem pencatatan akuntansi yang terkomputerisasi dengan basis program MYOB Accounting.

Berdasarkan uraian di atas, untuk meningkatkan cara pembuatan pelaporan keuangan dengan menggunakan software Accounting dengan tingkat pemahaman yang masih kecil dan kurangnya pelatihan.

Menurut Walter T. Harrison (2011:2) Laporan keuangan adalah dokumen bisnis yang digunakan perusahaan untuk melaporkan hasil aktivitasnya kepada berbagai kelompok pemakai, yang dapat meliputi manajer, investor, kreditor dan agen regulator.

Menurut Ikatan Akuntan Indonesia terdapat empat karakteristik laporan keuangan sebagai berikut : Dapat dipahami (understandability) ini berarti bahwa kualitas penting yang ditampung dalam laporan keuangan adalah kemudahannya untuk segera dapat dipahami oleh pemakai. Untuk maksud ini, pemakai diasumsikan memiliki pengetahuan yang memadai tentang aktivitas ekonomi dan bisnis, akuntansi, serta kemauan untuk mempelajari dengan ketekunan yang wajar.

Relevan (Relevance) Suatu laporan keuangandikatakan relevan apabila informasi yang disajikan dalam laporan keuangan tersebut memiliki manfaat, sesuai dengan tindakan yang akan dilakukan oleh pemakai laporan keuangan. Atau dengan kata lain, relevan merupakan kemampuan dari suatu informasi untuk mempengaruhi keputusan manajer atau pemakai laporan keuangan lainnya sehingga keberadaan informasi tersebut mampu mengubah atau mendukung harapan mereka tentang hasil-hasil atau konsekuensi dari tindakan yang diambil.

Keandalan (Reliability) yaitu keandalan merupakan kualitas informasi yang disampaikan laporan keuangan menyebabkan pemakai informasi akuntansi sangat tergantung pada kebenaran informasi yang dihasilkan. Keandalan suatu informasi sangat tergantung pada kemampuan suatu informasi untuk menggambarkan secara wajar keadaan/peristiwa yang digambarkan sesuai dengan kondisi yang sebenarnya.

Dapat

diperbandingkan (Comparability) Suatu laporan keuangan dapat diperbandingkan bila informasi tersebut dapat saling diperbandingkan baik antar periode maupun antar perusahaan

Dengan kondisi permasalahan pada Sekolah Menengah Kejuruan Yabri Simpang Tiga Kota Pekanbaru maka dirumuskan masalah bagaimana Peningkatan Keterampilan Penggunaan Aplikasi Mind Your Own Business (Myob) Accounting Bagi Siswa SMK Yabri Simpang Tiga Kota Pekanbaru Provinsi Riau.

Pengabdian kepada masyarakat ini mempunyai tujuan sebagai berikut : Meningkatkan Keterampilan Penggunaan Aplikasi Mind Your Own Business (Myob) Accounting Bagi Siswa SMK Yabri Simpang Tiga Kota Pekanbaru Provinsi Riau. Meningkatkan peran serta Fakultas Ekonomi Universitas Lancang Kuning dalam ikut serta mensosialisasikan penggunaan software akuntansi yaitu MYOB Accounting untuk memudahkan dalam memahami pengaplikasian dalam pelaporan keuangan bagi Siswa SMK Yabri Simpang Tiga Kota Pekanbaru Provinsi Riau. 


\section{METODE}

Metode Pelaksanaan untuk kegiatan pengabdian ini adalah dengan melakukan sosialisasi bagaimana membuat laporan keuangan sesuai dengan penerapan Akuntansi sesuai dengan standar yang berlaku umum dengan menggunakan softwae MYOB Accounting untuk siswa Sekolah Menengah Kejuruan (SMK) Yabri Kota Pekanbaru wilayah kecamatan Simpang Tiga Pekanbaru yang akan diambil sebanyak lebih kurang 30 Siswa.

\section{HASIL}

Tim dosen Fakultas Ekonomi Universitas Lancang Kuning mensosialisasi kemudahan penyusunan lapora keuangan dengan menggunakan Myob Accounting maka terlihat antusiasme peserta terhadap penggunaan software Myob Accounting lebih jauh. Antusisme dapat terlihat dari partisipasi peserta murid-murid SMK dan para guru mata pelajaran Komputer Akuntansi. Kemudian, dilanjutkan dengan simulasi software Myob Accounting dan sesi Tanya jawab terkait penggunaan Myob Accounting. Berdasarkan hasil pre dan post test yang diberikan kepada peserta, kami tim dosen Fakultas Ekonomi Universitas Lancang Kuning membuat rekapitulasi hasil pre dan post test tersebut. Rekapitulasi hasil pre dan post test ini dapat kita pada table berikut ini

Tabel 1 : Rekapitulasi jawaban kuesioner pre dan post test Kegiatan pengabdian kepada masyarakat

\begin{tabular}{|c|c|c|c|}
\hline No & Keterangan & $\begin{array}{l}\text { Pre } \\
\text { Test }\end{array}$ & $\begin{array}{l}\text { Post } \\
\text { Test }\end{array}$ \\
\hline 1 & $\begin{array}{l}\text { Apakah anda memahami } \\
\text { konsep pencatatan pada } \\
\text { laporan keuangan? }\end{array}$ & $50 \%$ & $90 \%$ \\
\hline 2 & $\begin{array}{lr}\text { Apakah } & \text { pencatatan } \\
\text { menggunakan } & \text { aplikas } \\
\text { penting? } & \end{array}$ & $40 \%$ & $70 \%$ \\
\hline 3 & $\begin{array}{l}\text { Apakah pada MYOB Acc } \\
\text { untuk Data Perkiraan harus } \\
\text { diubah terlebih dahulu? }\end{array}$ & $30 \%$ & $80 \%$ \\
\hline 4 & $\begin{array}{l}\text { Apakah pelunasan piutang } \\
\text { dengan cek dimasukkan ke } \\
\text { modul sales }\end{array}$ & $30 \%$ & $80 \%$ \\
\hline 5 & $\begin{array}{l}\text { Apakah pembayaran atas } \\
\text { pemasangan iklan dicata } \\
\text { dimodul sales? }\end{array}$ & $40 \%$ & $80 \%$ \\
\hline 6 & Apakah MYOB Accounting & $50 \%$ & $80 \%$ \\
\hline
\end{tabular}

\begin{tabular}{|c|c|c|c|}
\hline No & Keterangan & $\begin{array}{l}\text { Pre } \\
\text { Test }\end{array}$ & $\begin{array}{l}\text { Post } \\
\text { Test }\end{array}$ \\
\hline & $\begin{array}{l}\text { menyajikan Laporan Posisi } \\
\text { Keuangan? }\end{array}$ & & \\
\hline 7 & $\begin{array}{l}\text { Apakah MYOB Accounting } \\
\text { menyajikan Laporan L/R } \\
\text { Komprehensif? }\end{array}$ & $40 \%$ & $80 \%$ \\
\hline 8 & $\begin{array}{l}\text { Apakah MYOB Accounting } \\
\text { menyajikan Laporan Arus } \\
\text { Kas? }\end{array}$ & $30 \%$ & $80 \%$ \\
\hline 9 & $\begin{array}{l}\text { Apakah Perusahaan Jasa dan } \\
\text { Perusahaan Dagang } \\
\text { mempunyai pencatatan yang } \\
\text { sama? }\end{array}$ & $50 \%$ & $90 \%$ \\
\hline 10 & 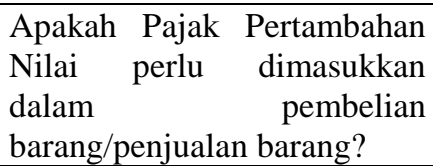 & $50 \%$ & $80 \%$ \\
\hline
\end{tabular}

Sumber : Pengolahan data excel 2015

Berdasarkan tabel 1 di atas, dapat dilihat bahwa terjadi perubahan yang sangat signifikan dalam menjawab pertanyaan sebelum dan sesudah kegiatan pengabdian kepada masyarakat (pre dan post test). Pengetahuan dan pemahaman peserta dalam penggunaan software myob accounting sebelum dilakukan sosialisasi myob accounting sangat rendah dimana hanya $50 \%$ yang menjawab mengetahui myob accounting dan hanya $40 \%$ yang menjawab mengetahui manfaat myob accounting serta hanya $30 \%$ yang menjawab bisa menggunakan aplikasi software myob accounting. Setelah dilakukan sosialisasi software myob accounting, pengetahuan dan pemahaman peserta dalam penggunaan myob accounting meningkat sangat signifikan. Hal ini terlihat bahwa 90\% menjawab mengetahui myob accounting dan $80 \%$ menjawab mengetahui manfaat myob accounting serta $70 \%$ menjawab bisa menggunakan aplikasi software myob accounting.

\section{PEMBAHASAN}

Hasil kegiatan pengabdian pada masyarakat yang telah dilakukan secara garis besar mencakup beberapa komponen, yaitu keberhasilan target jumlah peserta pelatihan, ketercapaian target materi yang telah direncanakan, ketercapaian tujuan pelatihan dan kemampuan peserta dalam penguasaan materi. Ketercapaian 
target jumlah peserta dapat dilihat dari jumlah peserta yang ditargetkan adalah 25 orang dan pada kenyataannya kegiatan diikuti sebanyak 25 orang sehingga target jumlah peserta telah dapat terpenuhi. Semua peserta dapat mengikuti seluruh proses simulasi dari awal sampai selesai, kegiatan yang dirancang $100 \%$ terlaksana, dan kehadiran kesiapan tim dosen $100 \%$. Target penyampaian materi simulasi juga tercapai karena materi dapat disampaikan secara keseluruhan. Dengan demikian maka tujuan kegiatan Pengabdian Kepada Masyarakat dapat terpenuhi.

Pengetahuan dan pemahaman peserta terhadap software Myob Accounting dievaluasi melalui jawaban post test yang meningkat signifikan dimana $90 \%$ sudah mengetahui Myob Accounting dan mengetahui manfaatnya, sebelumnya hanya 50\% yang mengetahui Myob Accounting dan $40 \%$ yang mengetahui manfaat Myob Accounting. Bahkan dengan sosialisasi yang dilakukan dengan cara simulasi satu kasus perusahaan maka terjadi optimisme peserta terhadap kemampuan menggunakan aplikasi software Myob Accounting dimana $80 \%$ menyatakan bisa menggunakan aplikasi software Myob Accounting. Hal ini berbanding terbalik dengan jawaban peserta sebelum dilakukan sosialisasi dimana hanya $30 \%$ yang menyatakan bisa menggunakan aplikasi software Myob Accounting

Berdasarkan evaluasi pelaksanaan kegiatan dapat diidentifikasi faktor pendukung dalam pelaksanaan program pengabdian kepada masyarakat adalah : Adanya kerjasama yang baik antara tim pengabdian kepada masyarakat dengan peserta siswa-siswa SMK dan Para Guru Mata Pelajaran Komputer Akuntansi SMK Yabri Simpang Tiga Kota Pekanbaru; Adanya kerjasama yang baik antara tim pengabdian kepada masyarakat dengan Kepala Sekolah SMK Yabri Simpang Tiga Kota Pekanbaru beserta jajarannya dalam mensupport terselenggaranya kegiatan ini dalam bentuk pemberian fasilitas ruangan, proyektor, menghadirkan peserta yang akan diberikan sosialisasi Myob Accounting serta kesediaan Kepala Sekolah SMK Yabri Simpang Tiga Kota Pekanbaru memberikan kata sambutan sekaligus membuka kegiatan pengabdian kepada masyarakat tersebut; Partisipasi aktif dan antusiasme yang tinggi dari peserta siswa-siswa SMK dan Para Guru Mata Pelajaran Komputer Akuntansi SMK Yabri Simpang Tiga Kota Pekanbaru dalam mengikuti seluruh rangkaian kegiatan.

\section{SIMPULAN}

Kegiatan pengabdian kepada masyarakat ini dilaksanakan di Kelas SMK Yabri dengan judul "Peningkatan Keterampilan Penggunaan Aplikasi Mind Your Own Business (MYOB) Accounting Bagi Siswa SMK Yabri Simpang Tiga Kota Pekanbaru Provinsi Riau" yang diadakan pada hari Sabtu, 07 November 2015 yang dihadiri oleh 25 Peserta, terdiri dari Siswa SMK dan Para Guru Mata Pelajaran Komputer Akuntansi SMK Yabri Simpang Tiga Kota Pekanbaru Provinsi Riau"

Sesuai dengan tujuan kegiatan pengabdian kepada masyarakat yang telah dilakukan, dapat diambil beberapa kesimpulan sebagai berikut : Meningkatkan peran serta Fakultas Ekonomi Universitas Lancang Kuning dalam ikut membantu sekolah sekolah menengah kejuruan yang baru berdiri dengan cara melakukan pembinaan terhadap SMK Yabri Simpang Tiga Kota Pekanbaru melalui kegiatan pengabdian kepada masyarakat dalam bentuk sosialisasi dan peningkatan penggunaan aplikasi software Myob Accounting untuk pelaporan keuangan bagi Siswa SMK dan Para Guru Mata Pelajaran Komputer Akuntansi SMK Yabri Simpang Tiga Kota Pekanbaru Provinsi Riau berjalan dengan baik dan lancar sesuai dengan yang diharapkan; Siswa SMK dan Para Guru Mata Pelajaran Komputer Akuntansi SMK Yabri Simpang Tiga Kota Pekanbaru Provinsi Riau telah memiliki pengetahuan dan pemahaman akan pentingnya penggunaan aplikasi software Myob Accounting dalam pelaporan keuangan yang mudah, cepat dan akurat; Pada pelaksanaan 
sosialisai, peserta diberikan kuesioner dalam bentuk pre dan post test, hasil dari pre dan post test tersebut menunjukkan perubahan yang sangat signifikan terhadap pengetahuan dan pemahaman peserta terhadap software Myob accounting; Berdasarkan kesimpulan di atas, maka dapat kami sarankan hal-hal sebagai berikut: Perlu adanya kegiatan pelatihan penggunaan software Myob accounting secara bertahap dan berkelanjutan sebagai lanjutan dari kegiatan sosialisasi ini, agar siswa-siswa SMK tidak hanya sekedar memiliki pengetahuan dan pemahaman terhadap software Myob accounting akan tetapi mereka benar-benar menggunakan software ini dalam membantu pelaporan keuangan dengan mudah, cepat dan akurat.

\section{DAFTAR RUJUKAN}

Ali Imran. 2009. 17 Jurus Mempelajari MYOB Accounting, Edisi Kesatu. Yogyakarta: Penerbit Andi

Hendra Wijaya, 2015. Excel Akuntansi, Jakarta : Penerbit PT Elex Media Komputindo

Reeve. 2005. "Accounting : Pengantar Akuntansi". Buku satu. Edisi dua puluh satu. Jakarta; Salemba Empat

Soemarso S. R. 2004. "Akuntansi Suatu Pengantar". Buku satu. Edisi lima. Jakata: Salemba Empat

Tanjung, Yulia, Haryani. 2009. Analisis Penerapan PSAK No.1 Tentang Penyajian Laporan Keuangan Pada PT.PLN (Persero) Area Padang. Jurnal Ekonomi dan kewirausahaan.

Yenti, Hidayah. 2010. Pelatihan Penyusunan Laporan Keuangan Koperasi bagi kelompok tani wanita "Panen Raya" di Kanagarian Tarok Kecamatan Baso Kabupaten Agam. Artikel Kegiatan Pengabdian Kepada Masyarakat.
Inova Fitri Siregar, 2014. Modul MYOB Accounting, Edisi Kesatu, Pekanbaru; Penerbit Pusat Teknologi Informasi dan Pangkalan Data UIN SUSKA Riau. 